\title{
NEW RECORD OF THE MOZAMBIQUE SCORPIONFISH, PARASCORPAENA MOSSAMBICA (PETERS, 1855) (ACTINOPTERYGII: SCORPAENIFORMES: SCORPAENIDAE), FROM ISRAEL, GULF OF AQABA, RED SEA
}

\author{
Ronald FRICKE ${ }^{1,2^{*}}$, Daniel GOLANI ${ }^{3}$, and Brenda APPELBAUM-GOLANI ${ }^{4}$ \\ ${ }^{1}$ Im Ramstal 76, 97922 Lauda-Königshofen, Germany \\ ${ }^{2}$ Staatliches Museum für Naturkunde, Rosenstein 1, 70191 Stuttgart, Germany [temporarily out of office] \\ ${ }^{3}$ National Natural History Collections and Department of Ecology, Evolution and Behavior, The Hebrew University \\ of Jerusalem, 91904 Jerusalem, Israel \\ ${ }^{4}$ Mt. Scopus Library, The Hebrew University of Jerusalem, 91905 Jerusalem, Israel
}

Fricke R., Golani D., Appelbaum-Golani B. 2015. New record of the Mozambique scorpionfish, Parascorpaena mossambica (Peters, 1855) (Actinopterygii: Scorpaeniformes: Scorpaenidae), from Israel, Gulf of Aqaba, Red Sea. Acta Ichthyol. Piscat. 45 (4): 423-425.

\begin{abstract}
The Mozambique scorpionfish, Parascorpaena mossambica (Peters, 1855), is recorded for the first time from the Gulf of Aqaba, Red Sea, based on a specimen collected at the north beach of Eilat, Israel at a depth of $10 \mathrm{~m}$. This finding also confirms the occurrence of the species in the Red Sea which was previously based on a doubtful record.
\end{abstract}

Keywords: marine fish, distribution, range extension, morphology, systematics

The Mozambique scorpionfish, Parascorpaena mossambica (Peters, 1855), was supposed to be widespread from east Africa to the Marquesas Islands, but was recently restricted by Motomura et al. (2011: 63) to the Indian Ocean, reaching from east Africa to western Indonesia. Outside this range, the species was recorded (as Scorpaena longicornis) from Sudan, Red Sea in checklist by Bamber (1915: 484), without any further data. The Red Sea record was cited but not discussed by several authors, but as no specimen was available and no information about the record had been provided, Golani and Bogorodsky (2010: 64) came to the conclusion that the record of $P$. mossambica could not be confirmed.

The genus Parascorpaena Bleeker, 1876 comprises a total of 8 valid species (Eschmeyer and Fricke 2015, modified according to Motomura et al. 2011): Parascorpaena armata (Sauvage, 1873) from the western Pacific; Parascorpaena aurita (Rüppell, 1838) from the Red Sea and East Africa to Australia, Andaman Sea, Philippines, Indonesia to Taiwan; Parascorpaena bandanensis (Bleeker, 1851) from Singapore, Indonesia and the Philippines; Parascorpaena maculipinnis Smith, 1957 from East Africa to the western Pacific Ocean; Parascorpaena mcadamsi (Fowler, 1938) from South and East Africa, Comores and La Réunion Island east to Marshall Islands, north to Taiwan, south to Western Australia, Queensland
(Australia), New Caledonia and Society Islands; Parascorpaena mossambica from East Africa to western Indonesia; Parascorpaena moultoni (Whitley, 1961) from Australia and New Caledonia; and Parascorpaena picta (Cuvier [ex Kuhl et Hasselt] in Cuvier et Valenciennes, 1839) from Sri Lanka east to Fiji, north to Taiwan, south to northern Australia.

A specimen of Parascorpaena mossambica from the northern Red Sea was recently discovered; it is described in the present paper. The Red Sea record of this species can now be confirmed.

On 13 October 1996, a $39.3 \mathrm{~mm}$ SL specimen of $P$. mossambica was collected by A. Miroz at Eilat, Israel, Gulf of Aqaba, Red Sea (Fig. 1), on a sand bottom with algae at $10 \mathrm{~m}$ depth. The specimen had been kept alive in an aquarium for some time after the capture. The specimen was deposited in the Hebrew University Fish Collection and received the catalog number HUJ 18340. Counts and measurements followed Hubbs and Lagler (1947); the classification follows Eschmeyer and Fricke (2015), the head spine terminology follows Eschmeyer (1969), finray counts follow Fricke (1983), references according to Fricke (2015).

Description. Dorsal-fin spines IX, dorsal-fin soft rays 9, anal-fin spines III, anal-fin soft rays 5, pectoral-fin rays 15. Lateral-line scales 43. Posterior lacrimal spine directed 


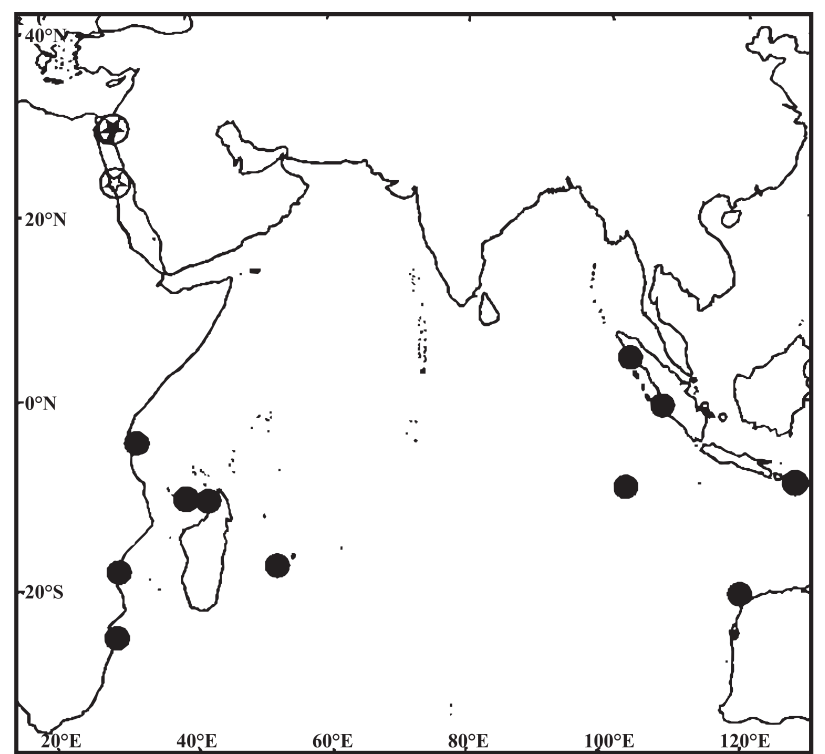

Fig. 1. Parascorpaena mossambica, Indian Ocean and Red Sea map with distribution of the species; Black star: new record from Gulf of Aqaba, white star: Sudanese record by Bamber 1915, Black circle: other records

anteriorly, suborbital ridge with three spines; occipital pit shallow. A large supraorbital tentacle present, longer than eye diameter, curved forward, with fringes and appendages.

Colour of fresh specimen (Fig. 2): Head and body yellowish brown, mottled with creamy white, also with dark brown spots. Supraorbital tentacle light brown, appendages creamy white. Suborbital region with an angular dark brown streak covered with blackish spots. Fins mottled with creamy white, bearing oblique brown streaks, membranes of spinous part of dorsal fin with distal orange streaks.

Remarks. This fish was first described (as Scorpaena mossambica) by Peters (1855: 434) from Ibo, Mozambique, western Indian Ocean. Referring to an unpublished revision of the genus by Eschmeyer and Rama-Rao, Eschmeyer (1986: 469-470) placed the species in the genus Parascorpaena Bleeker, 1876, and provided information on its distribution range from South and East Africa to the central Pacific. The species was recently restricted by Motomura et al. (2011: 63) to the Indian Ocean, occurring from South and East Africa to western Indonesia.

Playfair in Playfair et Günther (1867: 47) described Scorpaena longicornis from Zanzibar; this nominal species was synonymised with Parascorpaena mossambica by Dor (1984: 81-82). Parascorpaena mossambica was reported from La Réunion Island by Blanc and Postel (1958: 370, Scorpaena mossambica), from the Cocos-Keeling Islands by Allen and Smith-Vaniz (1994: 8), from Western Australia by Hutchins (2001: 27), from Sumatra (Indonesia) by Allen and Adrim (2003: 29, part), from Madagascar by Motomura et al. (2011: 63), from Flores (Indonesia) by Allen and Erdmann (2012: 225, part), and from Mayotte by Wickel et al. (2014: 192).

Records of $P$. mossambica (non Peters 1855) from eastern Indonesia and the western and central Pacific Ocean are based on the closely related species $P$. armata (Sauvage, 1873) according to Motomura et al. (2011: 63).

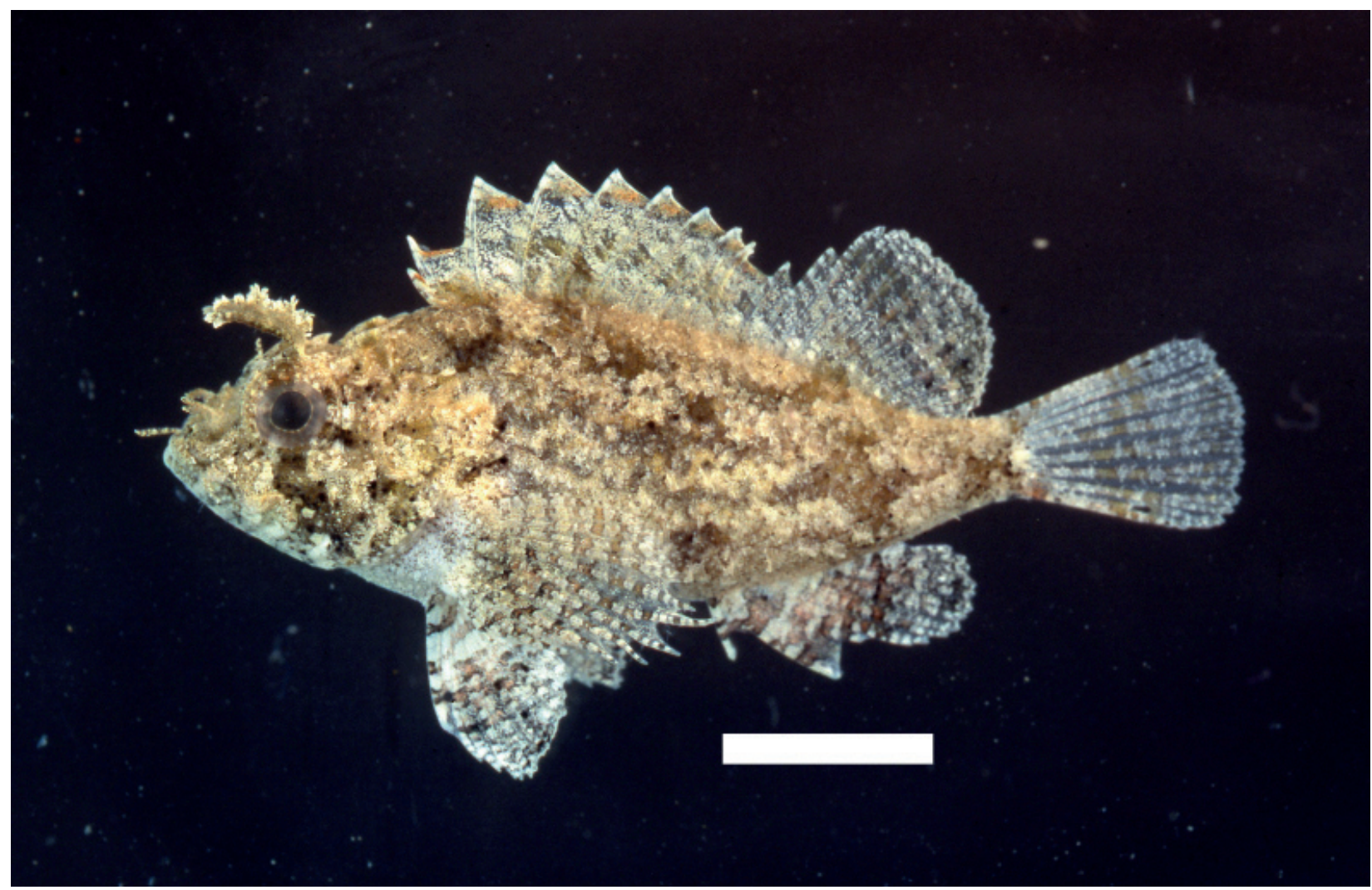

Fig. 2. Parascorpaena mossambica, HUJ 18340, 39.3 mm (SL), 13 October 1996, Eilat, Israel, Gulf of Aqaba, Red Sea; Photograph (C David Darom; Lateral view; Scale bar $=10 \mathrm{~mm}$ 
Parascorpaena mossambica was recorded from Sudan, Red Sea in checklist by Bamber (1915: 484, as Scorpaena longicornis), without any further data. The Sudan record was cited but not discussed by Dor (1984) and Goren and Dor (1994). As no specimen from the Red Sea was available in collections, and no information about the record had been provided, Golani and Bogorodsky (2010: 64) came to the conclusion that the record of P. mossambica could not be confirmed.

During the examination of scorpaenid fishes in the HUJ collection, the authors of the present paper discovered a specimen from Eilat, Israel collected in 1996 which they identified as Parascorpaena mossambica. The Red Sea record of that species can therefore now be confirmed; this also represents a first record from Israel and the Gulf of Aqaba.

The new, discontinuous distribution record of $P$. mossambica, with big gaps between the northern Red sea locality, the south-western Indian Ocean records from Mozambique, South Africa and La Réunion Island, and the eastern Indian Ocean records from the Cocos-Keeling Islands, western Indonesia and Western Australia, may be explained by the rarity of the species, which is also well camouflaged and therefore easily overlooked.

The present specimen was collected on a sand bottom with algae, at the north shore of Eilat, at a depth of 10 metres. The solitary and cryptic occurrence of this species makes it difficult to find it, so that it may be more widely distributed in the Indian Ocean than the scarce records of this species suggest.

In the Red Sea, other suitable habitats for this species may be found in the Gulf of Suez and in Eritrea, as well as on sand near coralline rock throughout the area. As the fish fauna of such habitats in most parts of the Red Sea is poorly known, it may have been missed so far, but is expected to be reported in future studies.

\section{ACKNOWLEDGEMENTS}

We would like to thank Aharon Miroz (Eilat, Israel) for collecting the HUJ specimen and bringing it to our attention, and to Dr. David Darom (HUJ, Jerusalem, Israel) for the photograph of the specimen.

\section{REFERENCES}

Allen G.R., Adrim M. 2003. Coral reef fishes of Indonesia. Zoological Studies 42 (1): 1-72.

Allen G.R., Erdmann M.V. 2012. Reef fishes of the East Indies. Vol. 1. Tropical Reef Research, Perth.

Allen G.R., Smith-Vaniz W.F. 1994. [Chapter 14] Fishes of the Cocos (Keeling) Islands. Atoll Research Bulletin No. 412: 1-21.

Bamber R.C. 1915. Reports on the marine biology of the Sudanese Red Sea, from collections made by Cyril Crossland, M.A., B.Sc., F.Z.S. XXII. The Fishes. The Journal of the Linnean Society of London, Zoology 31 (210): 477-485.

Blanc M., Postel E. 1958. Sur une petite collection de poissons de La Réunion. Mémoires de l'Institut Scientifique de Madagascar, Série F 2: 367-374.
Dor M. 1984. Checklist of the fishes of the Red Sea. CLOFRES. The Israel Academy of Sciences and Humanities, Jerusalem.

Eschmeyer W.N. 1969. A systematic review of the scorpionfishes of the Atlantic Ocean (Pisces: Scorpaenidae). Occasional Papers California Academy of Sciences No. 79.

Eschmeyer W.N. 1986. Family No. 149: Scorpaenidae. Pp. 463-478. In: Smith M.M., Heemstra P.C. (eds.) Smiths' Sea Fishes. Macmillan South Africa, Johannesburg, RSA.

Eschmeyer W.N., Fricke R. (eds.) 2015. Catalog of fishes. California Academy of Sciences, San Francisco. [Electronic version; Accessed on 11 December 2015.] http://www.calacademy.org/scientists/projects/catalog-of-fishes

Fricke R. 1983. A method of counting caudal fin rays of actinopterygian fishes. Braunschweiger Naturkundliche Schriften 1 (4): 729-733.

Fricke R. (ed.) 2015. References. Catalog of fishes. California Academy of Sciences, San Francisco. [Electronic version; Accessed on 11 December 2015.] http://research.calacademy.org/research/ichthyology/catalog/ fishcatmain.asp

Golani D., Bogorodsky S.V. 2010. The fishes of the Red Sea-reappraisal and updated checklist. Zootaxa 2463: 1-135.

Goren M., Dor M. 1994. An updated checklist of the fishes of the Red Sea. CLOFRES II. The Israel Academy of Sciences and Humanities, Jerusalem.

Hubbs C.L., Lagler K.F 1947. Fishes of the Great Lakes Region. Bulletin Cranbrook Institute of Science, Bloomfield Hills, MI No. 26.

Hutchins J.B. 2001. Checklist of the fishes of Western Australia. Records of the Western Australian Museum Supplement 63: 9-50.

Motomura H., Béarez P., Causse R. 2011. Review of Indo-Pacific specimens of the subfamily Scorpaeninae (Scorpaenidae), deposited in the Muséum national d'Histoire naturelle, Paris, with description of a new species of Neomerinthe. Cybium 35 (1): 55-73.

Peters [W.] 1855. Übersicht der in Mossambique beobachteten Seefische. Bericht über die zur Bekanntmachung geeigneten Verhandlungen der Königlichen Preussischen Akademie der Wissenschaften zu Berlin 1855: 428-466.

Playfair R.L., Günther A. 1867. The fishes of Zanzibar, with a list of the fishes of the whole east coast of Africa. John van Voorst, London.

Wickel J., Jamon A., Pinault M., Durville P., Chabanet P. 2014. Composition et structure des peuplements ichtyologiques marins de l'île de Mayotte (sud-ouest de l'océan Indien). Cybium 38 (3): 179-203.

Received: 18 May 2015

Accepted: 15 August 2015

Published electronically: 31 December 2015 